\title{
Mathematical Literacy as an Essential Criterion of Healthy Personality Development and of Effective Education with an Emphasis on Class Climate
}

\author{
Livia Hasajová ${ }^{*}$
}

\begin{abstract}
Personality development is determined by several factors; we have focused on the effect of mathematical literacy. Gaining new knowledge and skills not only from mathematics is influenced by class climate and the environment in which the educational process takes place. Key words: mathematical literacy, class climate, effective education, functional literacy.
\end{abstract}

\section{Introduction}

Mathematics is one of the most difficult sciences, with respect to skills necessary to cope with it. Logic, logical thinking, spatial perception, exact thinking, accuracy and concentration are not always a matter of course in students with mathematical literacy. Therefore, the focus is on the question of primary and secondary school students' level of knowledge of mathematics. Within the professional circles, the difficulty of the A-level in mathematics and even its change to a compulsory graduation subject is discussed vividly. Understanding the mathematical skills is a prerequisite for study in technical fields.

Mathematics is regarded to be the language of technique. The problem of the decreasing level of mathematical knowledge is transferred not only into higher level of education but also into practice. Weakened mathematical and scientific literacy lately arise as one of the principal obstacles in technical fields' development. The above mentioned trends are also confirmed by the PISA, TIMSS international research. The specific ability to learn certain activities necessary to human life is regarded to be the general definition of literacy by professionals. Among professionals, this term is often replaced by the term "functional literacy", whereas the term refers not only to acquire certain skills and knowledge developing personality of an individual, but also the ability to practically use that knowledge and skills in real life. According to various theoretical perspectives and views, we distinguish between several kinds of

Lívia Hasajová, Dubnica Institute of Technology in Dubnica nad Váhom, Dubnica nad Váhom, Slovakia; hasajova@dti.sk 


\section{Acta Technologica Dubnicae \\ volume 5, 2015, issue 3}

literacy, e.g. financial, numerical, mathematical, reading, health, scientific literacy etc. Mathematical literacy can also be found under the term numeracy between the components of functional literacy. The definition of mathematical literacy, according to J. Průcha, E. Walterová and J. Mareš (2009, p. 147), is based on OECD PISA sources and it is formulated as "the ability of an individual to identify and understand the role of mathematics in the world, to make well-founded mathematical judgments and deal with mathematics in a way that will meet the needs of the present and future life of the individual". According to an older definition it is "the ability to recognise and understand mathematical problems, deal with them and use mathematics in private life, in the employment and in the company of friends and relatives as a constructively involved and thoughtful citizen" (Straková, 2002, p. 11). The most frequently used definition is a formulation laid down for the OECD PISA international research: "Mathematical literacy is an ability of an individual to recognise and understand the role of mathematics in the world, to make well-founded judgements and to penetrate into mathematics so that it helps meet living needs of the individual as a creative, interested and thoughtful citizen." (Learning for Live - OECD PISA 2003 Research Results). The essence of mathematical literacy is, therefore, to understand the surrounding world and to be able to solve various social issues through mathematics.

\section{School climate and class climate in terms of education}

The term climate comes from Greek and means "prevailing weather conditions". The term climate is not used only in this context. We use this term also to describe the particular environment, "prevailing conditions" of the environment. In pedagogy, the terms class climate, school climateand school environment climate are often used (Petlák, 2006, p. 15). The notions of school and class climate are very closely related to the terms of school and class environment and atmosphere. The learning environment is beyond the social-psychological aspect and refers to the physical environment as well (class lightning, class equipment, wall colours and other), whilst the class atmosphere is current, it is a short-term condition in the class, often changing, sometimes even during a teaching unit (Gavora, 1999, p. 239).

There are various factors affecting school or the class climate (teachers, students, parents, environment and others) but also interactions between teachers and students or between the students themselves. Just because school or class climates are affected by several factors, we cannot talk about universal climate. The group of students in a class can, however, act differently with different teachers. The experience shows that whilst one teacher experiences a rather negative class climate, another teacher perceives it as non-problematic. It means that a variety of factors participate in the class climate (Petlák, 2006, p. 18). 


\section{Acta Technologica Dubnicae \\ volume 5, 2015, issue 3}

Class climate is, in fact, a summary of subjective evaluations and selfevaluations of the perception, experiencing, emotions and mutual interactions of all participants, which evocate in them, as co-creators and consumers, educational and other activities in a given environment (Čapek, 2010, p. 13). A positive perception of school is in the interest of each educational organisation. By modernisation of material resources, by application of innovative teaching methods and forms into the educational process, schools have an impact on the after-school environment and other determinants, which in mutual relation contribute to modelling the school life. School life and school spirit are the terms characterising a school as a whole in the positive or negative sense. A positive or negative perception of school is based on feelings we get at the entrance to each school. One of the reasons of the mentioned feelings is the fact, that after entering a school, school climate affects us immediately. Each school has its own specific climate that affects the educational process taking place in the school, social relationships in the school, motivation, the results achieved in each area of school work. If we visited several schools, we would have got the impression, that despite relative similarity they are not the same. The difference is just in the school climate. School climate is a state present in the educational practice. By its nature, it creates a school's image not only for the society but also for the participants of school life (Petlák, 2011, p. 99). School represented by a certain hierarchy of relationships in which they equally apply specific rules, principles, norms and conditions for their functioning and existence in every-day life. If these conditions are respected and complied with by all the actors of school life, then the system works well. Its actors are happy, feel safe and can develop and use their skills. The principles closely related to a school are respect for the positions and status of individual people, filling the roles that are necessary for the existence of a school's system. The actors of school life, which are students, teachers and other employees, represent the consumers within the school context. School climate is also affected by the administrative workers', school caretaker's, maintenance man's, and cooks' willingness or unwillingness. Parents, administrative staff and local authority employees also intervene in the school climate, whether directly or indirectly (Petlák, 2011, p. 109). The school should seek the satisfaction of all participants of school life. It cannot only support teachers and suppress the opinions of pupils and students, nor can it be under the pressure from parents and focus only on a small group of students. The director should not restrict the creativity of teachers and consider the school to be his/her private company. Also teachers should not feel threatened by their students on one hand, but on the other hand they are obliged to follow the rules and the school's internal procedures (Čapek, 2010, p. 215). 


\section{Acta Technologica Dubnicae \\ volume 5, 2015, issue 3}

\section{Conclusion}

With respect to the positive effects of climate in the school environment, mathematics comes into the centre of attention of education. The interest of students in studying mathematics arise their interest in technical subjects. The level of mathematical knowledge will be strengthened, which will be transferred not only into the higher level of education but also into practice.

The paper was written as a part of the research task KEGA 036UKF-4/2014 "Influencing Aggressive Behaviour of Students by Means of Creating a Positive School and Class climate."

\section{References}

Čapek, R. (2010). Tř́ini klima a školní klima. Praha: Grada.

Gavora, P. (1999). Aki sú moji žiaci? Bratislava: Práca.

Gillernová, I., \& Krejčová, L. et al. (2012). Sociální dovednosti ve škole. Praha: Grada.

Hanuliaková, J. (2008). Klíma triedy a jej význam v tvorivo-humanistickej výchove. Výchova $\mathrm{v}$ pedagogickom výskume a praxi. In Zborník medzinárodnej konferencie Výchova $v$ pedagogickom výskume a praxi. Trnava: FF UCM, 2008.

Hanuliaková, J. (2010). Kreovanie klímy triedy v edukačnej praxi. Bratislava: IRIS.

Hvozdík, S. (2001). Psychologické pohl'ady na edukáciu a postmodernizmus. Prešov: FF PO.

Kačáni, V. et al. (1999). Základy učitel'skej psychológie. Bratislava: MEDIA TRADE - SPN

Kyriacou, C. (2004). Kličcové dovednosti učitele ( $2^{\text {nd }}$ ed.). Praha: Portál

Manniová, J. (2008). Učitel'v procese výchovy a vztahov. Bratislava: Axima.

Mareš, J. (2001). Sociální opora. In Sborník učitelé a zdraví 3. Brno: PÚ AV ČR.

Mareš, J. (2013). Pedagogická psychologie. Praha: Portál.

Petlák, E. (2006). Klíma školy a klíma triedy. Bratislava: IRIS.

Petlák, E. et al. (2011). Kapitoly zo súčasnej edukácie. Bratislava: IRIS.

Petlák, E. (2014). Aktuálne otázky edukácie. Bratislava: IRIS.

Průcha, J. (2002). Moderní pedagogika. Praha: Portál.

Sklenár̆ová, N. (2013). Interakce a komunikace učitele v edukačnem procesu. Ostrava: PF OU. 